\title{
The Pluralism of Identities and Major Preferences of Freshwomen and Sophomore ELT Students
}

\author{
Hardianti $^{1}$ and Sahril Nur ${ }^{2}$ \\ ${ }^{1,2}$ Universitas Negeri Makassar, Indonesia \\ *: hardiantiharun651@gmail.com
}

\begin{abstract}
This paper discusses the diversity of identities possessed by English Language Teaching (ELT) students, as prospective English language professionals, both in terms of their socio-cultural and linguistic pluralism. In addition, the complexity of the problem of determining majors that are still often encountered in the field will also be part of the discussion in this paper. By using the narrative study method, data were collected by analyzing the results of reflections carried out by the research subjects on how they view themselves as individuals and also members of diverse communities, their experiences before starting their study period as students of English education, what strategies they overcome difficulties during their study, especially since the pandemic until at the present time. Subject selection is done by purposive sampling method. This paper is expected to provide a useful reference for students and lecturers in analyzing needs at the beginning of the study period and helping students solve the problems they experience related to major preferences, with the provision of a good introduction to the identity of prospective ELT professionals. This will support their success in language education that prioritizes respect for the linguistic and cultural diversity of others as an inseparable part of this global and unpredictable era. Furthermore, the idea is expected to give valuable insights for Transformative English Studies.
\end{abstract}

Key words: ELT students, major preferences, plural identity.

\section{Introduction}

The phenomenon of unemployment has become a global issue, especially during the COVID-19 pandemic. The Indonesian Central Statistics Agency (BPS) noted that the number of open unemployment in Indonesia reached $8,746,008$ people in February 2021. The number increased by $26.3 \%$ compared to the same period last year. The majority of Indonesia's openly unemployed are high school graduates or public high schools. The number reached 2,305,093 people as of February 2021. Meanwhile, Vocational High School or Vocational High School followed with $2,089,137$ unemployed people. Junior High School is right below it because there are still 1,515,089 people who do not work. The smallest number of unemployed comes from those who do not or have never attended formal education. However, the Directorate of Higher Education Research and Technology, Ministry of Education, Culture, Research, and Technology noted that every year there are around 1.7 million new graduates [1], indicating high numbers of impact toward the unemployment case. However, the problem of unemployment is not enough to be 
seen from the aspect of the workforce, because there are structural issues of employment that must be given special attention, including job security, link and match education and the needs of the labor market [2]. Therefore, this paper underlines the importance of exploring the ELT students' identities as well as their major preferences.

Some students are motivated by potential economic returns, others want to take engaging classes, and others still would like opportunities to help people in their jobs [3]. Before coming to meeting those objectives, students should remember that there are several things that should be put in the first place. That is by understanding themselves so that they can understand others better. This is related to identities.

Exploring identities are essential to increase the awareness of own language and culture is threatened with extinction as well as meeting the demands of global world. Some researchers have mostly focuses on exploring teachers' identities [4]-[6] and many also have shifted their views more on students or learners' identities [7]-[10]. Language learning develops essential 21st-century skills that require students to participate in face-to-face interactions via technology, internships, and volunteer opportunities in the community, apply their competence in a new language to their career and personal goals, broadening their thinking beyond self-serving goals, and also become more skillful in understanding diverse cultural perspectives and their own identity [11].

All of these are identities: age, gender, religious or spiritual affiliation, sexual orientation, race, ethnic origin, and socioeconomic position. Certain identities are plainly visible to others (such as ethnicity or presumed gender), whereas others are internalized and not always visible (like a disability, socioeconomic status, or education level). Throughout history, the greater society has defined, given significance to, and elevated many identities. Because faculty and instructors have the ability to affect students' classroom experiences, it is critical for faculty and instructors to understand social identities in order to actively promote all-encompassing learning environments for all students. Moreover, any step along the path of identity discovery enables ELT educators to have a better understanding of the extent to which their student teachers' ideas are influenced by their involvement in ELT courses and the teacher education system as a whole [10].

\section{Theoretical Reviews}

Identity is a crucial concept in language acquisition research because it refers to how a person views his or her connection to the world, how that relationship is organized through time and place, and how the individual interprets future possibilities [12]. In line with that, this article tries to provide an overview to the reader about the experiences and orientations of ELT students in the educational process, including their inner struggles in making important choices. Pluralism of identities, the term that appeared on the surface, is used to indicate the nature of complex diversities exist in the world with no exception in the academic world.

In a department that applied linguistics plays the most role, the identity of ELT students may be seen from their cultural and linguistic views. In language learning, culture and language are two things that cannot be separated. It also reminds us of the chicken and egg theory, who knows what came first. What is clear, culture and language are absolute things in language learning and teaching, as experienced by students who are the subjects of this research.

From the linguistics perspective, it is no doubt that Indonesia was gifted by the existence of huge varieties of languages. Although Indonesian is the national language and lingua franca and that is highly valued as the dominant language in all official settings, such as school, government, religious practice and is the main language for informal interaction in urban contexts as well [13], Indonesia is the home of approximately 718 local languages throughout the country[14]. In Central Sulawesi, where the researcher live and work, there are: Totoli, Tombatu, Taa, Seko, Sangihe Talaud, Saluan, Pipikoro, Pamona, Lauje Malala, Kulawi, Kaili, Dondo, Buol, Bungku, Besoa, Banggai, Balantak, Balaesang, Bajo, Bada, Jawa , Bugis, Makassar, Bali, Toraja, Sundanese, Malay, Gorontalo languages, and possibly other undiscovered languages.

Certain identities are plainly visible to others (such as ethnicity), whereas others are internalized and not always visible (like a disability, socioeconomic status, or education level). Throughout history, the greater society has defined, given significance to, and elevated many identities. Because faculty and instructors have the ability to affect students' classroom experiences, it is critical for faculty and instructors to understand social identities in order to actively promote inclusive learning environments for all students.

\section{Identity and Major Preferences}

According to Weinreich (1969) "A person's identity is defined as the totality of one's self-construal, in which how one construes oneself in the present expresses the continuity between how one construes oneself as one was in the past and how one construes oneself as one aspires to be in the future." [15]. This definition is an inclusive one and directs attention to the totality of one's identity at a given phase in time. The definition applies to the young child, the adolescent, the young adult, and the older adult in various phases of the lifecycle.

There is also a concept of identity proposed by Norton. He stated that identity is 'discursively constructed' and 'always socially and historically embedded'. This means that the kind of person people claim to be is always open 
to challenge and redefinition with shifts in the discursive context. On the other hand, this new identity might be seen by others as incompatible with theirs; it might be contested and thus has to be constantly re-assessed and re-negotiated under new social power relations [16].

The third theoretical framework of identity presented in this paper is AQuadripolar Model of Identity by Taylor. This Quadripolar Model of Identity postulates the existence of four self-components (private, public, ideal and imposed), whose pluridirectional interactions may lead to four types of self-system (submissive, duplicitous, rebellious and harmonious) hypothesized to differ from one relational context to another (e.g., school, family, friends). For students, these identity processes are expected to fluctuate depending on the subject studied [17].

A study conducted by Soutar and Turner reveals that there are four most significant factors of institution selection by the students: course fit, academic reputation, employment prospects, and teaching quality, which has implications for educational administrators establishing marketing strategies and programs [18]. The different case happens when the students are not adequate enough to such classical issues like low capitals and so forth. It is like the case of talking $4 \mathrm{G}$ technology to someone who even does not have access to electricity in his home

\section{Methodology}

The findings of the article are developed through narrative research. It is the study of individuals' lives as told through the stories of their experiences, including discussions about the meaning of experiences for them [19]. The first strategy utilized in narrative research is to distinguish the various forms of narrative research based on the authors' analytical strategies [20]. According to Polkinghorne [20], this technique employs a paradigm of thought to provide a description of the topic that encompasses and transcends the tale or story type categorization system. This narrative analysis focuses on the researcher's collection of descriptions of events or occurrences and then configuring them into a plot. Chase takes a position that is quite similar to Polkinghorne's notion of narrative analysis, believing that academics may do storytelling studies based on paradigmatic reasons, such as how humans are empowered and forced by social resources, how they are socially positioned in interactive performances, and how storytellers build interpretations [20].

A longitudinal study will be better to explore more about someone's development. However, narrative research enables the researchers to guide the subjects by retelling their previous counters. It's important to learn from the past, planning for something better in the future. Six students from a different year of studying in the English Department of Universitas Muhammadiyah Luwuk were selected as the research subjects. A set of open-ended questions was given during the interviews both in offline and online environments

\section{Findings and Discussion}

Narrative studies may concentrate on a particular setting, such as a teacher or student in a classroom, an organization's narrative, or a tale presented about an organization [20]. By using this method, data were collected by analyzing the results of stories by the research subjects on how they view themselves as individuals and also members of diverse communities, their experiences before starting their study period as students of English education, what strategies they overcome difficulties during their study, especially since the pandemic until at the present time. Five students became subjects in this study with several considerations. Two students are from the first semester and the other three students are from the third semester. They were initially selected purposively and conveniently based on the consideration of ease of access to information. One more student was finally chosen as an addition to complete the previous four students (see table 1 ).

Table 1. : Students' Demographic Information

\begin{tabular}{cclc}
\hline No & Student & Ethnics & Semester \\
\hline $\mathbf{1}$ & A & Saluan & $\mathbf{1}$ \\
$\mathbf{2}$ & B & Saluan/Bungku & $\mathbf{1}$ \\
3 & C & Saluan & 3 \\
4 & D & Banggai & 3 \\
5 & E & Banggai & 3 \\
\hline
\end{tabular}




\title{
Students' Narratives
}

\section{Student $A$}

Student A is not born to a multiple ethnicity family. She has postponed studying at the university level for more than five years. During her gap year, she had learned English more, before finally deciding to choose that subject as her major. She explains:

"Most of the learning materials are from books and Google. But for speaking, it's because I'm an introvert, so I learn through songs. Watch more Disney movies."

She dreamt of becoming a doctor but as she realized that many things did not go well, she turned her focus on the English specialty. She has two siblings. If she will be able to finish her study in university, she will be the first bachelor in her family. Besides studying, she has also helped her parents by working in a public office.

"I have many dreams one of those is to become successful in the future, makes my family happy and travelling around the world. More specifically, she used to have a dream of becoming a doctor. My surroundings is very nice. My neighbors are very friendly and we can help each other. They know a lot about me and my family. Cause, my neighbors are my family. "

Student A first' English lesson was when she was in elementary school. English was just a compulsory subject. The lesson was not taught continuously until the end of her elementary school year

"Get to know and be interested without being serious about focusing. When I was in elementary school, I liked hearing people speak English. When in the elementary school, I like to hear anyone who speaks English. They look like a smart and cool person."

Her learning mostly depended on the school's teacher. Surely it's about the way the teacher delivers the materials. As she explained:

\begin{abstract}
"I don't know what happened to me, but in school, the learning depended on the teacher and the way it was delivered in teaching. So sometimes if the teacher is good at two things, it's actually easy to learn, but mostly it's just about the material in the book, so you get confused and don't understand the concepts being taught. I have a favorite English teacher in high school. The way the material is delivered is relaxed and easy to understand. He speaks a lot and gives many examples maybe because he taught in an English village, Kediri if I remember correctly. He didn't teach restricted on what the textbook tell to do".
\end{abstract}

After about five years of postponing applying for a program in university, she finally decided to choose English department. But starting a new year as university student after some gap years is not easy, and it's even worse because of the pandemic. She said that being a new university student is a little bit shocking.

\begin{abstract}
"Lecture schedules are not as orderly as school schedules, maybe because the lecturers are busy. The course schedule is uncertain, the first time I got that I was a little upset, it's not a big problem, the difficulty is more on yourself. I am in a phase where studying while working has more difficulty with time management. This online course helps me because I have to study and have to work too. Difficulty understanding course material, so far there have been no obstacles, still fine. Get to know and be interested without being serious about focusing.".
\end{abstract}

Student A has not decided what will she become in the future. She said that choosing English is very good to support her in her workplace. She said that she will just follow the rules, try her best, but have not decided if she will become an English teacher or not.

\section{Student B}

Student B is also born to a single ethnic couple. She is a fresh year student of the English Department of UM Luwuk. She has been interested in English since childhood. She likes to watch English cartoons. She went to a vocational high school, majoring in accountancy. But she still has a passion for English. She used to follow English courses in the past but she had some bad experiences related to the administrative system of the course that made her quit. She said that she also has the interest to visit foreign countries and one of the requirements is to be able to speak English. That's why she's even more enthusiastic to explore knowledge in the field of English. She adds:

“.. Basically all jobs that are related to or in the field of English, I like them, Mam., Like become a tour guide, Mam."

Student B's parents have passed away. Therefore, to support her and her brother and sister's life and schools, she also works in a barbershop.

"About my study time, such as for courses, it depends on the schedule. It's like there is a direct assignment to work right away. It's only for learning that adds knowledge and insight outside of the courses at most nights. As soon as there is a task that is given, it will be completed as much as possible. If it can be completed at that time, then work on it immediately, to minimize the pile of tasks. Besides, if there are college matters that require going to campus or there are assignments that require a meeting to ask permission at work."

Student B is very enthusiastic about learning English. She learns a lot from the aids of today's technology.

"I learn English mostly through watching movies or vlogs of YouTubers who are Indonesian but study abroad. Usually it's also through songs, but songs are more likely to practice speaking. It's also normal to play OME TV and directly train skills with people from foreign countries. 
She does not have serious problems during her study as ELT student. The main problem during the covid19 pandemic relies on the network connection.

"The difficulty is more with the network. It's like while the zoom is suddenly out of light or the network is gone, even though the lecturer while explaining finally missed it."

\section{Student C}

Student $\mathrm{C}$ is from a village in Bualemo district, more than 70 kilometers away from Banggai regency city center. Her parents also come from a single tribe. She went to an Islamic private high school in her village.

Her first ever encounter with English was when she was in the 3rd grade of elementary school, but English was no more included in the main timetable of the schedule until she was in junior high school. Moreover, her English in elementary school teacher often missed the class.

"I started to have interest in English since junior high school. I started to like listening to English songs."

Student $\mathrm{C}$ was inspired by her neighbor, a master of linguistics who is currently teaching English in a course place.

"I am interested in becoming an English teacher because since junior high school at my school the teacher always does not come in every English lesson. Sometimes I ask, where is the teacher? In addition, I was inspired by my neighbor who is now a lecturer. Besides, I also like English."

It is interesting that besides English, she is also learning Russian. She knows the simple pattern of introduction and also alphabets in Russian. She is an easy-going person and not a shy person. She likes to take a part in public activities like the general elections in her village. It's not difficult to find her in such activities. So, in the first place, student $\mathrm{C}$ chooses English for her future professional orientation.

\section{Student D}

Student D is from Banggai Laut. She has Banggai ethic from her parents. However, she also understands Banggai language, Bajo language, a little bit of the Buginese language although not as fluent as Indonesian. English is the only foreign language she currently learning. She has a dream to be a teacher, but to be an English teacher is a dream she's just started to assemble.

Student D started her first journey earlier than the previous students. She started to learn it in kindergarten. However, getting an early start did not leave a clear mark. She remembered her memories in elementary school when the teachers in the school are out of numbers compared to the students. No need to hope for an English teacher because even other subjects also have no special teachers. Such conditions are not a new thing in such conditions in Indonesia.

The same thing when she was in junior high school. English was not seen as important as the other subjects.

"We were taught only like 'How are you?', just like that. I study English seriously only after I have become a student in English Department. I watch cartoons, because they are not as difficult as adult films for me to understand. I also learn from Eng-Breaking application, since 1 month ago. That online learning application will be accessible until six months."

Student $\mathrm{E}$ is an active learner. As the researcher observe, she is very willing to join certain activities with her friends and also get a good sense of initiating her own learning although she said a different case. She has a close friend and that friend helps her, motivates her to speak.

"We often practice English when we meet. My friend is more excited to start the conversation, use English, and I reply her. Her vocabulary mastery is good."

During this pandemic, she still has the same problem like many of her friends do.

"....What I feel maybe all my friends also feel is the first is financial constraints, the second is the network because where I live there is no network I had during the pandemic before going to Luwuk I had to go back and forth up and down the mountain why didn't I ...I went back to Luwuk again because of the cost, so for 2 semesters I tried to be patient for it and the third obstacle was when we didn't study directly, I think because the network is sometimes less friendly, I usually don't really understand the material."

Student D will also be the first bachelor in her family. She hopes to study English better and will eventually graduate with a good result.

\section{Student $E$}

Student $\mathrm{E}$ is from Bokan, Banggai Laut. She speaks Indonesian and Banggai but she also understands Bajo language. She is the youngest of two siblings. At first, her parents do not earn much that finally made her turns her focus from becoming a medical professional to being a future English professional. She wanted to follow her brother to become a medical professional. However, her story is just pretty much valuable to miss. Her mother is a housewife and her father is a fisherman. Her turning back time will tell that changing her mind was more than just financial reason. 
"I've known English since elementary school. I just got the materials of ABC, numbers, etc. But the teacher was not an English teacher. And in elementary school, English lessons are only local content. Only until I became a senior high school student that the motivation to learn English had developed. I was excited when there is a tourist visited my village. That foreigner can speak Indonesian and she was very kind."

Student E said it by showing her picture with the woman. Student $\mathrm{E}$ felt that if she could speak English, she could communicate more with the foreigner.

"In high school I actually took the concentration of health, it's a vocational school (SMK) majoring nursing. My mother had doubts about me because she wanted to major in PBI. I want to be a tour guide. I want to be a teacher too, just because I'm interested. It's good because when teaching, (we) can help the students to add their knowledge. We can help them to expand their knowledge. Because they actually know the materials) but only the basics."

She adds that when she had practice at the hospital, for blood transfusions on patients, but she could not control herself. She suddenly fainted after seeing blood. Then she realized an important thing. Being a nurse would be problematic for someone who suffers from hemophobia.

Then, in her second year as an ELT student, Student $\mathrm{E}$ is on her journey to fulfill her new dreams: becoming a tour guide or English teacher. Student $\mathrm{E}$ is student D's close friend. They often have a conversation in and after the class. Besides learning English, Student $\mathrm{E}$ is also currently learning Korean.

Five selected ELT students have shared their journeys to the English program. Some have no fixed future job orientations while some have settled themselves to be English-related jobs in the future. Indeed, in some cases presented in this article, issues like academic reputation, employment prospects, teaching quality, come later after the financial issues and course fit, particularly if it is connected to a private component (see [21]).

In a situation during pandemic and post-pandemic, understanding identities and major preferences is a good thing to help educators design learning activities that will benefit the students, including their intellect and emotions, rather than just one or the other to create a secure and sound educational atmosphere. This reminds us of a humanistic approach by Maslow, Rogers, and Bugental. Humanistic educators think that information and emotions are inextricably linked throughout the learning process [22].

\section{Conclusion}

The journey of the students which has been described in the findings section certainly does not stop there. There are still many stages of life that they will experience, as befits the nature of learning that will be experienced throughout one's life. The identity that has been formed today is sometimes different from the existing one and still has the possibility to change along with the life experiences that everyone has, including students. This article is expected to give insight on understanding identity and how important that thing to take into account in major preferences. However, it is still very much needed in future works about how the identities development and major preferences are seen from different perspectives, like between female students and male students, first-year students and senior students, and so forth. Furthermore, a study about the integrated humanistic approach for certain courses in English education is also needed.

\section{Acknowledgements}

Special acknowledgment is sent to our dearest students for sharing their stories, giving such valuable and great lessons for the researchers, and hopefully, it will also help to motivate them.

\section{References}

[1] D. B. Raharjo and S. Aranditio, "Jutaan sarjana lahir tiap tahun kemendikbudristek jangan jadi pengangguran intelektual," Suara.com, 2021.

[2] A. Faizal, "Sarjana Pengangguran," Identitas Unhas, 2021. [Online]. Available: https://identitasunhas . com/ sarjana-pengangguran/. [Accessed: 28-Nov-2021].

[3] N. Quadlin, "From Major Preferences to Major Choices: Gender and Logics of Major Choice," Sociol. Educ., vol. Vol 93, no. 2, pp. 91-109, 2020.

[4] F. Rostami, M. H. Yousefi, and D. (2020). Amini, "Gaining favorable identities of Iranian EFL teachers: A single case study of transition from elementary schools to universities," Res. Sq. Platf. LLC, 2020.

[5] H. Choe, "Identity formation of Filipino ESL teachers teaching Korean students in the Philippines: How negative and positive identities shape ELT in the Outer Circle," English Today, 2016. 
[6] A. Simon-Maeda, "The Complex Construction of Professional Identities: Female EFL Educators in Japan Speak out.," TESOL Quarterl, vol. 38, no. 3, p. 405, 2004.

[7] A. SARIÇOBAN and O. KIRMIZI, "Investigating the relation between pre-service EFL teachers' epistemic cognition, instructional preferences and perceived engagement beliefs," Dil ve Dilbilimi Çalışmaları Derg., vol. 17, no. 2, pp. 979-993, 2021.

[8] S. Shields, "Learner Identities. Palgrave Studies in Gender and Education," Palgrave Stud. Gend. Educ. by Springer Int. Publ., pp. 59-74, 2021

[9] F. Anjanillah, R. Wahyudi, and S. Syafiyah, "EFL Learners' Multiple Identities Constructions in Relation to Global Positions of English. The Qualitative Report," 2021.

[10] P. Safari, "Iranian ELT Student Teachers' Portrayal of Their Identities as an English Language Teacher: Drawings Speak Louder than Words," J. Lang. Identity Educ., vol. 19, no. 2, pp. 125-141, 2019

[11] American Council on the Teaching of Foreign Language (ACTFL), Opening Statement.

[12] B. Norton, Identity and Language Learning: Extending the Conversation. Bristol: Multilingual Matters, 2013

[13] M. B. Jafar, "An Ecological Approach to Researching Biliteracy Development of Indonesian Bilingual Children In Australian Social Contexts," School of Communication and the Arts Victoria University, Australia, 2010

[14] L. Kemendikbud, "Bahasa Daerah di Indonesia," 2018.

[15] P. Weinreich, "Identity Structure Analysis," in Analysing Identity Cross-cultural, societal and clinical contexts., P. Weinreich and W. Saunderson, Eds. Taylor \& Francis e-Library, 2005.

[16] B. Norton and K. Toohey, "Identity, language learning, and social change.," Lang. Teach., vol. 44, 2011

[17] F. Taylor, "A Quadripolar Model of Identity in Adolescent foreign Language Learners," University of Nottingham, 2010.

[18] G. Soutar and J. Turner, "Students' Preferences for University: A Conjoint Analysis," Int. J. Educ. Manag., vol. 16, pp. 40-45, 2002

[19] J. Schreiber and K. Asner-Self, Educational Research: The interrelationship of questions, sampling, design, and analysis. Wiley/Jossey-Bass Education, 2011

[20] J. C. Cresswell, Education Research, Planning, Conducting and Evaluating Qualitative and Quantitative Research, 4th ed. Boston: Pearson, 2012.

[21] F. Taylor, "A Quadripolar Model of Identity in Adolescent Foreign Language Learners," University of Nottingham,

[22] C. Hare, "An Introduction to Humanistic Learning Theory," Medium.com, 2019. [Online]. Available: https: //medium.com/age-of-awareness/an-introduction-to-humanistic-learning-theory-1489cdde6359. [Accessed: 30-Nov-2021]. 